KYIV-MOHYLA

HUMANITIES JOURNAL

KYIV-MOHYLA SCHOLARLY PEER-REVIEWED JOURNALS

Memoralization of Lenin: Legislation and Attitudes (On the Materials of Kyiv, Vinnytsia and Cherkasy Regions)

Author: Oleksandra Gaidai

Source: Kyiv-Mohyla Humanities Journal 2 (2015): 137-154

Published by: National University of Kyiv-Mohyla Academy

http://kmhj.ukma.edu.ua/ 


\title{
Memoralization of Lenin: Legislation and Attitudes (On the Materials of Kyiv, Vinnytsia and Cherkasy Regions)
}

\author{
Oleksandra Gaidai \\ National Academy of Science of Ukraine, \\ Institute of History of Ukraine
}

\begin{abstract}
Despite more than 20 years of independence, Ukraine's former political system has not vanished, as it had created and left behind immense material and cultural resources. The new, often weaker system is not able to obliterate or eliminate signs of the past completely. Thus, cleansing or preserving a landscape feature is an act of historical politics and represents national needs and expectations. In this context, the main question is how do Ukrainian authorities incorporate the Soviet heritage, in our case political monuments, into the cultural and public space of modern Ukraine? The present research scrutinizes the politics of memory towards the Soviet past in contemporary Ukraine. It looks at policies towards Soviet heritage in political monumental art at the governmental and local levels in central Ukraine. The article analyses official documents on Soviet heritage in Ukraine, the conditions of its enactment and the specifics of implementation. Secondly, the research investigates the activities of local authorities in protecting or demounting Soviet monuments. Finally, the analysis examines the attitudes of the population, which include both actions and views. The "ground" level analysis helps us to avoid misleading generalizations in the field of historical politics and discloses the way that politics of memory is perceived and shared among the population.
\end{abstract}

Key Words: monument, politics of memory, Lenin, heritage, central Ukraine.

"Wait, Kyiv still had a Lenin statue?"2

The former republics of the Soviet Union and communist states of Central and Eastern Europe (the so-called Eastern Bloc) adapt different strategies in the elaboration of their communist heritage, but, in general, there are two alternatives: to destroy or to preserve. With the collapse of an authoritarian regime, dismantling of the monuments is an important symbolic act

Research for this publication has been sponsored by the SNF Grant CR11IL_135348 "Region, Nation and Beyond. A Transcultural and Interdisciplinary Reconceptualization of Ukraine."

2 The first reaction of the foreign journalist to the news about tearing down the statue of Vladimir Lenin in Kyiv on 8 December 2013. Uri Frieman, “The Remarkable History Behind Ukraine's Toppled Lenin Statue," The Atlantic, December 8, 2013, accessed December 9, 2013, http://www.theatlantic. com/international/archive/2013/12/the-remarkable-history-behind-ukraines-toppled-leninstatue/282141. 
of breaking away with the former ideology for the newly independent state. The choice is determined, on the one hand, by the historical experience of the country, and on the other, by a certain vision of its future. English historian David Harvey indicates that, in the process of heritage creation, society selects part of the inherited imagined past in order to paste it into the imaginary future heritage. ${ }^{3}$ That makes the cornerstone of memory policies, which, according to Ukrainian analyst Larysa Nahorna, can be defined as a political process with goalsetting in order to develop the "image of the past" as an effective tool for influencing public opinion. ${ }^{4}$ Memory policy is not limited to the activities of government agencies, but rather represents a complex of all existing social practices in the articulation and preservation of historical memory. However, due to financial resources, the role of the government is often the most significant. Thus, the Soviet heritage, as an analytical category, helps to trace the changes in memory policy in independent Ukraine. Memory policy is being considered as a general way of governing, which finds its realization in memory politics in the sense of practices.

The Soviet heritage in monumental art can be divided into three categories: communist, military, and cultural heritage. This paper targets the objects that belong to the first category monuments to Soviet statesmen, especially to Lenin. Soviet memorialization policy in Ukraine began with Lenin's decree of erecting monuments to revolutionaries and progressive artists in 1919. But those first monuments were made out of cheap materials (plaster, concrete), so they were quickly demolished. ${ }^{5}$ In the 1920 , with the establishment of the Soviet regime in Ukraine, the process of honoring Soviet political and public figures started with the new regime. The central status among them was given to Lenin, who became the object of general veneration, elevated to the level of worship. The monuments to Lenin were erected in the centre of each town in front of the local council or, if it was a small town, near semi-formal buildings such as the "palace of culture," schools, etc. ${ }^{6}$ In 1991, there were 8,248 objects of monumental art in the Ukrainian Soviet Republic, including 5,015 statues of Lenin. ${ }^{7}$ This number is quite impressive, considering that, at the time, the Ukrainian republic had 448 cities and 926 towns. Thus, the standardization of the monumental embodiment of Lenin, along with the great number of the monuments, has developed one of the best-known symbols of the Soviet era.

3 David Harvey, "Heritage Pasts and Heritage Presents: Temporality, Meaning and the Scope of Heritage Studies," International Journal of Heritage Studies 7.4 (2001): 326.

4 Larysa Nahorna, "Polityka pamiati ta ii oriientatsiina misiia," ["Politics of Memory and its Orientation Mission,"] in Kultura istorychnoi pamiati: ievropeiskyi ta ukrainskyi dosvid, ed. Iu. Shapoval (Kyiv: IPIEND, 2013), 116.

5 Konstiantyn Bakhanov, "Novi chasy — novi heroi: Formuvannia kultury pamiati v Ukraini," ["New Times - New Heroes: The Formation of Cultural Memory in Ukraine,"] in Kultura istorychnoi pamiati: ievropeiskyi ta ukrainskyi dosvid, ed. Iu. Shapoval (Kyiv: IPIEND, 2013), 196.

6 John Lehr and Natalia Aponiuk, "Memory, Myth, and Monuments: The Commemoration of a Contested Past in western Ukraine," Memory Connection 1.1 (2011): 217; Oksana Mihaitva, "Sotsialnyi prostir mista: Mozhlyvosti 'prochytannia' ta upravlinnia," ["The Social Space of the City: Possibilities of 'Reading' and Management,"] Herald of Donetsk National University. Series Sociology 8.3 (2007): 413. Dmytrii Chobit, "Nazdohaniaiuchy viky," ["Catching the Ages,"] Holos Ukrainy, October 2, 1992, 12. 
French historian Pierre Nora defines monuments as the "place of memory," where the memory of the community is formed, represented and honoured. ${ }^{8}$ So, considering its role in identity establishment, most of the monuments are erected by the state. But a close relationship between authority and monuments leads to a situation in which the change of political orientation results in alteration of the monuments based on a "new era - new heroes" principle. The situation becomes more complicated when the old system preserves some legitimacy after its collapse. Ukraine's independence was not a result of revolutionary events, but, rather, it was a compromise among local party elites. Therefore, in the development of memory policies, the former communists had to construct a new national narrative and pantheon of heroes, while the former regime and its heritage were not completely discredited.

This paper scrutinizes policies towards Soviet statesmen monuments on governmental and local levels in central Ukraine. It also targets the local population's attitudes towards this part of the Soviet heritage. The central Ukraine region could be presented as the "battlefield for memory," where different evaluation models of the Ukrainian past, especially its Soviet period, compete equally. This region includes 5 to 8 administrative units; however, we will focus only on three of them - Vinnytsia, Kyiv and Cherkasy regions. Although there are supporters of the Communist Party and the right-wing political party "Svoboda" 9 in these regions, the bulk of the population prefers "centrist" forces that take a moderate position on most of the controversial issues (for example, language).

Among Ukrainian researchers who contributed to the topics of memory policies and historical memory in Ukraine are V.Kravchenko, H. Kasianov, L. Nahorna, Iu. Shapoval, V. Kulyk, Ia. Hrytsak, A. Portnov, N. Iakovenko and others. Based on the data of sociological surveys and analyses of history textbooks, they outlined the major questions and challenges in the area. However, the topic of memory policies on the Soviet heritage in monumental art remains undeveloped. Partly, this situation is due to the lack of a single general register of the monuments in Ukraine and in the politicization of this topic, as the question of Soviet heritage often becomes a tool in political debates.

\section{Memory Policies towards Soviet Heritage in Independent Ukraine}

The process of Soviet statesmen monuments dismantling in Ukraine started in the western region in 1990, when the national democratic political party "Narodnyi Rukh" had leading positions in the local authorities. The Ternopil Council of People's Deputies was the first to adopt the decision to demolish the monuments to Vladimir Lenin, Karl Marx and Vladimir

8 Pierre Nora, "Vsemirnoie torzhestvo pamiati," ["The Worldwide Celebration of Memory,"]

Nieprikosnoviennyi zapas 2-3 (2005), accessed October 10, 2014, http://magazines.russ.ru/nz/2005/2/ nora22.html.

9 According to the data of the Central Election Committee in the Parliamentary election of 2012, the Communist Party of Ukraine received: in Vinnytsia province - 8.86\% of votes, Cherkasy province - 9.29\%, Kyiv province - 6.11\% and Kyiv - 7.23\%. Political party VO "Svoboda": Vinnytsia - 8.40\%, Cherkasy - 9.48\%, Kyiv province - $10.8 \%$ and Kyiv - 17\%. Accessed at http://www.cvk.gov.ua/pls/vnd2o12/. 
Zatonskii on 18 July 1990, only two days after the Parliament issued the Declaration of State Sovereignty of the Ukrainian SSR. ${ }^{10}$ During the following weeks, Lenin monuments were removed from Chervonohrad, ${ }^{11}$ Kolomyia, Boryslav, Drohobych, Radekhiv, Mykolaiv (Lviv and Ivano-Frankivsk regions). ${ }^{12}$

In response, the Presidium of the Supreme Soviet of the Ukrainian SSR, headed by Leonid Kravchuk, issued the Decree On Violation of the Law of the Ukrainian SSR "On the Protection and Usage of Historical and Cultural Monuments." ${ }^{13}$ City councils were asked by central authorities to revise their illegal decisions on monument demolition and relocation, while the Council of Ministers of the Ukrainian SSR was instructed to "make up an inventory of the historical and cultural monuments in the country in order to determine their actual historical, architectural and cultural value." The position of Leonid Kravchuk was ambiguous as, on the one hand, he disapproved of the cases of monument demounting, but, on the other, he tried to avoid conflicts with local authorities. Thus, at a press conference held on 12 September 199o, he stated that "everyone may have different views about Lenin, however, we (as a nation) would lose the respect of the civilized world if we treat his monuments that way."14 Nevertheless, it seems that neither his cautious choice of words nor the resolution of the Supreme Soviet influenced the local authorities in western Ukraine. Only two days after the press-conference, the Lviv City Council decided to dismantle the Lenin monument in the city centre, which was done immediately after the Council session..$^{15}$

Along with the demounting in 1990, the first acts of vandalism of Soviet monuments were recorded on the territory of the Ukrainian republic. Unlike in western Ukraine, in the eastern and southern regions, the acts of vandalism were only a manifestation of anti-communism without any nationalistic motives. ${ }^{16}$ Still, those events caught limited response from the state and the public, as the economic and political crisis pushed the issues of Soviet heritage to the margins of contemporary political processes.

The problem of constructing memory policies that would reflect new national needs and expectations emerged after Ukraine gained independence in 1991, and due to that, the issue of measures towards Soviet statesmen monuments appeared. The history of memorial

10 "Voina s pamiatnikami," ["Monuments at War,"] Pravda Ukrainy, July 21, 1990, 2.

11 "Demontirovan pamiatnyk Leninu," ["Monument to Lenin Demounted,"] Pravda Ukrainy, August 2, 1990.

12 “Kommunisty Kolomyi protestuiut," [“Communists Protest in Kolomyia,"] Pravda Ukrainy, August 24, 1990, 2.

13 Resolution of the Parliament USSR No 270-XII/1990 "On the Violation of the Law of the Ukrainian SSR 'On the Protection and Use of Historical and Cultural Monuments,'” The Bulletin of the Parliament of the USSR, 40 (1990), 536.

14 "Pres-konferentsiia Leonida Kravchuka," ["Press Conference of Leonid Kravchuk,"] Pravda Ukrainy, September 14, 1990, 3 .

15 "Demontirovan pamiatnik Leninu v Lvove," ["Monument to Lenin Demounted in Lviv,"] Pravda Ukrainy, September 16, 1990, 2.

16 Georgii Kasianov, Ukraina 1991-2007: Narysy novitnoi istorii [Ukraine 1991-2007: Essays on Contemporary History] (Kyiv: Nash chas, 2008), 24. 
policy development in Ukraine since gaining independence can be divided into four periods, according to the terms of four presidents: Leonid Kravchuk (1991-1994), Leonid Kuchma (1995-2004), Viktor Yushchenko (2005-2010) and Viktor Yanukovych (2010-2014).

Leonid Kravchuk, the first President of Ukraine, was a former communist, as were the majority of deputies in the Ukrainian Parliament. The first Parliament, functioning until 1994, consisted of former members of the Supreme Soviet of the USSR with the communist "Group 239" dominating. Therefore, there was no lustration and the Communist Party, banned in 1991 by a Decree of Parliament, ${ }^{17}$ was restored in 1993. The Constitutional Court decided that there were no legal reasons for banning the party and it was recreated under the leadership of Petro Symonenko.

Due to multiple challenges to nationhood, including a non-established national identity in Ukraine, the first President and his administration tried to implement a balanced and restrained national historical narrative and pantheon of heroes. However, even cautious efforts in memory policies raised opposition in the Eastern and Southern regions of Ukraine. As a result, in 1994, Leonid Kuchma won the presidential election to a large extent by promising to protect the rights of the mentioned regions' population. Furthermore, in his desire to be the President of both parts of Ukraine, according to historian Iaroslav Hrytsak, Kuchma put all his efforts into reconciling the national and Soviet paradigms and thus, controversial figures and events were avoided in memory policies. Therefore, his presidency resulted in a well-practiced ambivalence $^{18}$; for instance, erection of a monument to figures of the new historical narrative of Ukraine (e.g., Mykhailo Hrushevskyi) was accompanied by preservation of communist monuments (e.g., Lenin monuments).

The Communist Party of Ukraine had been winning the Parliament elections during the nineties, although the number of its seats decreased. ${ }^{19}$ Only in 2002 another political force, namely Viktor Yushchenko's Coalition “Nasha Ukraina," obtained more votes, receiving 70 seats in the Parliament, while the CPU had only 59. Henceforth, it was not a surprise that the issues related to the fate of the Soviet heritage and de-communization in general had been removed from the agenda of the Ukrainian parliament in the nineties.

Among important factors of power revitalization in determining the policy on Soviet heritage, including monuments, was an event that took place in 200o, defined as the "Velvet Revolution" by representatives of pro-presidential forces. Eventually, it highlighted the ideological component of struggle against left-wing parties, especially the Communist Party, for gaining control in the Parliament. In January 200o, after prolonged negotiations with possible allies, the pro-presidential forces formed a majority consisting of 237 deputies.

17 Decree of the Parliament of Ukraine No 1468-XII/1991 "On Banning the Communist Party of Ukraine," accessed December 14, 2013, http://search.ligazakon.ua/1_doc2.nsf/link1/T1468oo.html.

18 Iaroslav Hrytsak, "Istoriia v osobakh: Do formuvannia istorychnoi pamiati v Ukraini, 1991-2011," [“Personalities: On the Issue of the Formation of Historical Memory in Ukraine, 1991-2011,"] in Kultura istorychnoi pamiati: ievropeiskyi ta ukrainskyi dosvid, ed. Iu. Shapoval (Kyiv: IPIEND, 2013), 237 .

19 In the parliament elected in 1994 the Communist Party received 99 seats, in 1998 the Communist Party - 84 seats. Accessed at: http://www.cvk.gov.ua/pls/vd2002/WEBPROC15V?kodvib=129.03.1998. 
However, the left-wing parties' blockade of the Parliament did not allow the new coalition to dismiss its "left" Chairman Oleksandr Tkachenko. After two weeks of debates, the propresidential majority left the Parliament building and, on 1 February 200o, moved to the cultural and exhibition centre "Ukrainskyi Dim" and elected a new chairman, Ivan Pliushch. They also adopted the Resolution on replacing Soviet symbols on the facade of the Supreme Council with state symbols of independent Ukraine. ${ }^{20}$ However, this decision was not developed into a united policy of eliminating the symbols of Communism in Ukraine's public sphere. Leonid Kuchma only issued the Decree "On the Question of Usage of Ukrainian State Symbols." Its 4th article specified: "The Council of Ministers of the Autonomous Republic of Crimea, regional, Kyiv and Sevastopol City State Administrations [...] should ensure the deconstruction of buildings, removal of state symbols of former USSR and Soviet republics, slogans of the USSR, with exception of cases, when the aforementioned symbols are located on buildings, included into the list of monuments of history and culture."21 The Decree did not compel local authorities to obligatory removal of Soviet regime symbols; hence, there was space for maneuverer and compromise with the pro-Soviet forces. Therefore, dismantling of monuments in the nineties had clear regional differences: from the complete destruction of the Soviet statesmen monuments in western Ukraine and selective removal in Central regions to no action at all in Southern and Eastern Ukraine. As a result, 15 out of 25 regional capital cities in Ukraine had monuments to Soviet statesmen, often on their main squares or streets. In several cases, there was more than one monument in the city, for instance, 17 in Donetsk, 33 in Dnipropetrovsk, 5 in Mykolaiv, etc. ${ }^{22}$

The Orange Revolution in 2004 and Viktor Yushchenko's election lead to significant changes in memory policies. According to historian Georgii Kasianov, President Yushchenko used historical policy as the ideological base for construction of the Ukrainian nation, and the Great Famine [Holodomor] was put in the centre of these policies. ${ }^{23}$ Under the President's patronage, a huge memorial to the Holodomor was erected in Kyiv, museums and exhibitions were opened all around the country. In spite of clear anti-Soviet memory policies, Viktor Yushchenko did not support the request of "Ukrainian People's Party" to issue a direct order on the destruction of Soviet regime symbols across the whole Ukrainian territory. Instead, in 2007, on the eve of the next anniversary of the Holodomor of 1932-1933, he signed a Decree demanding local authorities to demount monuments of people involved in the organization of the famine and political repressions. ${ }^{24}$ The fact that the Decree did not include a comprehensive list of historical figures,

20 Kasianov, Ukraina 1991-2007, 247-48.

21 Decree of the President of Ukraine No 1143/2001 "Issues on Usage of State Symbols of Ukraine," accessed December 13, 2013, http://zakon4.rada.gov.ua/laws/show/79/2001.

22 "Znaky totalitarnoho Molokhu, iaki ne uviishly do Derzhavnoho reiestru nerukhomyh pamiatok Ukrainy," ["Symbols of Totalitarian Remnants, not Included in the State Register of Ukraine,"] Kultura izhyttia 49-52 (2009): 19-41.

23 Georgii Kasianov,"Holodomor i stroitelstvo natsii," [“The Holodomor and Nation Building,"] Pro et Contra 3-4 (2009): 29 .

24 Decree of the President of Ukraine $N^{\circ}$ 250/2007 "Commemorations of the $75^{\text {th }}$ Anniversary of the Holodomor 1932-1933 in Ukraine," accessed December 13, 2013, http://un.mfa.gov.ua/ua/act/open/ id/2034. 
whose monuments had to be removed, created much room for interpretation. ${ }^{25}$ Nationalistic forces tried to use the Decree as a legitimization for demounting Lenin statues. The other problem was that the Soviet statesmen monuments were included in the State register of monuments of Ukraine. Only in 2009, on the proposal of local cultural heritage agencies, around 2,80o monuments and memorials were removed from the State register. ${ }^{26}$ Removal from the register meant that the state renounced its responsibility to take care of those monuments. From that moment, their fate fully depended on the local authorities. In the same year, another decree concerning the commemoration of the Holodomor ${ }^{27}$ was adopted. It reiterated the point about the dismantling of monuments devoted to people participating in the organization and implementation of the Holodomor and political repressions in Ukraine. In some way, this Decree represented an attempt to push local authorities to dismantle monuments to Soviet statesmen, but the response of local authorities was rather sluggish.

President Viktor Yanukovych, elected in 2010, in fact, returned to the policy of Leonid Kuchma, within which the Soviet and national paradigms were combined. However, the Soviet monuments clearly dominated over the others ideologically and quantitatively. Monuments to Soviet statesmen remained in the cities' centres, thus the new monuments were often placed in peripheral parks and squares. The national narrative appeared to be in a disadvantageous position from the beginning. The problem with the Communist monuments was that they represented a state, which no longer existed; however, only a few monuments representing the Ukrainian national idea and the country's struggle for sovereignty had been erected since 1991.

Thus, the fate of Ukraine's Soviet heritage in political monumental art was not resolved. For decades, the government avoided any public discussions on this issue. Instead of the development of a long-term strategy on overcoming the Soviet legacy, Ukrainian state authorities adopted certain decisions determined by the needs of the political debate, which provoked even more tensions around the monuments. The event that radically changed the situation was the decision to exclude the Communist monuments from the State register of monuments.

25 But if demounting monuments of such odious Soviet statesmen as Stalin and Molotov could be explained by fulfillment of the aforementioned Decree the case of Lenin is more complicated. Lenin died long before the full-scale repressions and the famine had commenced. It was endorsed by the Kyiv Appeals Court that, in 2010, in its resolution on the Holodomor, among organizers indicated only Stalin, Molotov, Kaganovych, Postyshev, Kosior, Chubar and Hataievych. "Decision of the Kyiv Administrative Court of Appeal 2a-817/11/2316, 2 August, 2012," accessed December 13, 2013, http:// pravoscope.com/act-uxvala-sudu-2a-817-11-2316-tverdoxlib-v-a-o2-o8-2012-administrativni-spravi-s. See "Znaky totalitarnoho Molokhu."

27 Decree of the President of Ukraine No 432/2009 "On Additional Measures to Commemorate the Victims of the Holodomor of 1932-1933 in Ukraine," accessed December 13, 2013, http://zakon4.rada. gov.ua/laws/show/432/2009. 


\section{The Strategies of Local Authorities in Dealing with Monuments to Soviet Statesmen (Vynnytsia, Kyiv and Cherkasy Regions)}

In the 199os, the dismantling of Soviet statesmen monuments in the Central regions occurred rarely and mainly concerned the most notorious and damaged monuments, made of non-casting materials in the 1940s-196os. According to the list of Soviet monuments removed from the State register of monuments of Ukraine, in 2009, there were 540 monuments to Soviet statesmen in the Cherkasy, Kyiv and Vinnytsia regions. In Cherkasy, 214 out of 230 monuments were dedicated to the founder of the Soviet state. 75 out of 96 monuments in Vinnytsia and 204 out of 214 in Kyiv were statues of Lenin. ${ }^{28}$ It is obvious that the quantity of monuments to other Soviet figures in comparison to the monuments to Lenin is considerably insignificant. Among other Soviet and Party figures memorialized in Soviet era monuments we should mention M. I. Kalinin, V. I. Chapaiev, M. V. Frunze， G. I. Petrovskii, F. E. Dzerzhynskyi, M. O.Shchors, I. M. Sverdlov, V. V. Kuibyshev, G. M. Dymytrov, O. M. Gorkii, and G. I. Kotovskyi. To sum up, the concentration of monuments to Soviet political figures, especially monuments to Lenin, was extremely dense in the central regions of Ukraine.

Despite the lack of reliable information about the monuments' dismantling in the early nineties, we could consider the situation in central regions' cities. In 1991, the Kyiv City Council adopted a decision to remove a sculptural group devoted to the October Revolution, including a statue of Lenin, from the central square of the city. But the statue of Lenin on the Shevchenko Boulevard remained untouched. ${ }^{29}$ As there was a danger of open clashes in the city of Vinnytsia, in 1992, the authorities ordered to demount the Lenin monument late at night and workers were advised to wear body armour. ${ }^{30}$ In Cherkasy, city mayor Serhii Odarych decided to remove the statue of Lenin from the central square only in 2008. Demounting of the monument was carried out at night on November 27 with five cranes, but the monument fell down and broke into several pieces. ${ }^{31}$ The process was captured on camera and subsequently the video appeared on the Internet. The public outrage that followed the demounting of the Lenin monument made it one of the most notorious cases in central Ukraine. However, it was the methods and forms of the monument demounting that caused public disapproval rather than the idea of its relocation itself. For instance, only a small number of Communist Party supporters stepped out in defence of the Lenin statue in Cherkasy.

28 See "Znaky totalitarnoho Molokhu."

29 The sculpture of the monument was created by Sergei Merkurov, a man famous for making a plaster "death mask" of Lenin on the night he passed away. It was designed for a Soviet exhibition at New York City World's Fair in 1939. In the Ukrainian capital the Lenin sculpture was installed in 1946.

30 "Pamiatnyk-pryvyd, abo kudy podily Lenina z tsentralnoi ploshchi Vinnytsi," ["The MonumentPhantom, or where the Lenin Monument was Taken from the Central Square of Vinnytsia,"] 20 minutes, March 13, 2013.

$31 \quad$ "V Cherkassakh vo vremia demontazha pamiatnik Lenina raskololsia na chasti," ["In Cherkassy the monument to Lenin split into parts during its dismantling,"] News.ru, November 28, 2008, accessed August 10, 2013, http://rus.newsru.ua/ukraine/28nov20o8/leninı.html. 
Later in 2011, a court acknowledged the decision of the Executive Committee of the Cherkasy City Council to move the Lenin monument as illegitimate, and obliged the local council to restore it. ${ }^{32}$ Demounting of the monument in Cherkasy occurred while the monument was still under government protection, being included in the State register of monuments. Hence, the court stated that the local authorities did not follow necessary procedures; in particular, they did not take measures to agree their decision with the Cabinet of Ministers of Ukraine and did not create comprehensive project documentation. ${ }^{33}$ Despite the legal decision, the Lenin statue was not reinstalled and the square was put under full-scale reconstruction.

When making decisions on dismantling Soviet monuments, Ukrainian local authorities referred to the above-mentioned presidential Decree of 2007. In some cases, monuments were removed openly with participation of official representatives (e.g., in 2008 in Chyhyryn), ${ }^{34}$ while, in most cases, dismantling was carried out at night by anonymous individuals. For instance, in the town of Talne (Cherkasy region), the Lenin statue was tied to a car and dragged off at night, on 6 November 2008. Despite the fact that the monument was situated on the central square in front of the city council, the attempt to identify and catch the violators had failed. ${ }^{35}$ A similar situation occurred in the town of Myronivka (Kyiv region), where in 2009 some unknown persons pulled down the statue of Lenin from its pedestal.

The most frequent causes for removal of the monuments included: reconstruction of the area, installation of another monument, or absence of active supporters of the memorialized figures. In 2012, in the town Shpola (Cherkasy region), deputies of the nationalistic party "Svoboda" initiated the process of the demounting of the Lenin statue standing on the territory of the local sugar plant. They managed to persuade their colleagues that the time to get rid of the monument had come. ${ }^{36}$ In 2013, in the town of Iampol (Vinnytsia region), the Lenin statue was replaced with the statue of Cossack Hetman Bohdan Khmelnytskyi; in turn, the statue of Lenin found its place at the local art museum ${ }^{37}$. It should be mentioned that a few years prior to the incident, Iampol had a strong Communist opposition, thus the process of Lenin monument dismantling was repeatedly blocked. A similar situation occurred in the town

32 "Meria Cherkas maie povernuty pamiatnyk Leninu na mistse!" ["The City Hall of Cherkasy Should Return the Statue of Lenin to Its Place!"] Communist Party of Cherkassy, August 7, 2012, accessed September 10, 2013, http://www.kpu.ua/ru/41515/meriya-cherkas-maye-povernutipam\%25e2\%2580\%2599yatnik-leninu-na-misce.

33 Decision of the Kyiv Administrative Court of Appeal.

34 "Pamiatnyk Leninu v Chyhyryni," [“The Monument to Lenin in Chyhyryn,"] Shukach, September 20, 2012, accessed February 1, 2013, http://www.shukach.com/uk/node/13969.

35 Borys Pavlenko, "Illich z Talnoho pishov unochi," ["Illich Left Talne at Night,"] Personal, September 2-8, 2009.

36 "Ieshche v odnom ukrainskom gorode demontirovan pamiatnik Leninu," ["Monument to Lenin Demounted in Yet Another Ukrainian City,"] Zhytomyr.info, accessed June 22, 2012, http://www. zhitomir.info/news_109152.html.

37 “Vid vinnytskykh komunistiv z Iampolia 'vtik' Lenin," ["Lenin ‘Escapes' from Communists in Iampil,"] Vinnitsa.info, September 25, 2013, accessed November 1, 2013, http://www.vinnitsa.info/news/vidvinnitskih-komunistiv-z-yampolya-vtik-lenin.html. 
of Kalynivka (Vinnytsia region), where the Lenin monument on the main square remained the subject of conflict for many years. On 26 May 2011, members of the City Council adopted the decision to remove the monument. 19 deputies voted "for," two voted "against" the decision and the remaining 12 abstained. ${ }^{38}$ However, the city mayor Anatolii Shamaliuk managed to block the implementation of this decision. The monument was not only preserved, but also restored and painted in gold. The other vivid example of debates over Lenin statues occurred in the town of Kaniv (Cherkasy region). There, the nationalistic forces claimed that a statue of the former Soviet leader could not stand in the town where the Ukrainian national symbol, Taras Shevchenko, is buried..$^{39}$ Looking ahead, it should be noted that this monument, as well as the Lenin statue in Kalynivka, was brought down on 22 February 2014. ${ }^{40}$

Among possible solutions to the problem of Soviet heritage monumental art in Ukraine, the so-called "Park of the Soviet Period" should be mentioned. Such a park could become a tourist attraction and satisfy the supporters of preserving the Soviet heritage. ${ }^{41}$ Still, there are several possible drawbacks; Soviet statues assembled together on one territory could hyperbolize the Communist reality and turn the park into an object of Communist kitsch. Rodney Harrison, an expert on cultural and historical heritage, points out that the representation of Communism in such parks fluctuates between irony and desire to put down or desecrate the regime; besides, the strictness and triumph of the statues could provoke laughter among the majority of tourists. ${ }^{42}$ However, it is indisputable that having no other workable solutions, except full destruction, states continue to support the creation of such parks.

In Ukraine, the idea of a Soviet Monuments Park was discussed only in Kyiv and only after the Kyiv City State Administration initiated the dismantling of 27 Soviet monuments ( 9 of them were Lenin statues) in 2008, following the Decree of 2007. But only private initiatives have actually been implemented so far. For instance, Anatolii Tarkovskyi, the resident of Bershad (Vinnytsia region), installed a full-sized sculpture of Lenin, that was previously demounted in one of the neighboring villages, in his own yard. Tarkovskyi is convinced that part of the Soviet period was not as bad as it is presented today; therefore, he collected various artifacts

38 “Kalynivka: My ne khochemo Lenina," [“Kalynivka: We do not Want Lenin,”] 20 minutes, January 22, 2013, accessed January 25, 2013, http://2ominut.ua/Novyny-Kalynivky/Vid-Chytachiv/1025965o. "Pamiatnyk Leninu v Kanevi proponuiut znesty miski deputaty," ["Deputies Propose to Dismantle Monument to Lenin in Kaniv,"] Kaniv, April 2, 2013, accessed April 20, 2013, http://www.kaniv.net/ news.php?p=24406\&vc=0. "Leninopad tryvaie: vozhdia skynuly v Kanevi, Mykolaievi, Khersoni," [“The 'Lenin Fall' Continues: Lenin Toppled in Kaniv, Mykolaiv, Kherson,"] TSN, February 22, 2014, accessed March 1, 2014, http:// tsn.ua/ukrayina/leninopad-trivaye-vozhdya-skinuli-v-kanevi-mikolayevi-hersoni-336o67.html.

41 Duncan Light, "An Unwanted Past: Contemporary Tourism and the Heritage of Communism in Romania," International Journal of Heritage Studies 6.2 (2000): 169. 
from the Soviet era. ${ }^{43}$ His desire to preserve the remnants of the Soviet past could be explained by nostalgia and fear of losing not only the communist ideology, but also the memory of it.

Thus, there is no consistent policy regarding the Soviet statesmen monuments in central Ukraine. Depending on various political and socials factors, the monuments were preserved or dismantled across the regions. The decision to pass authority over Communist monuments to local councils resulted in further differentiations between provinces and even neighboring communities.

\section{The "Pros" and "Cons" for Lenin Monuments: Public Attitudes}

The people's attitudes towards Soviet statesmen monuments are determined by the memory policies on the Soviet past in Ukraine after gaining independence. In the situation where the "Ukraine as the colony of the Russian Empire and the Soviet Union" metaphor has turned into an interpretative framework, the Soviet heritage in monumental art was treated as "inconvenient" and even "alien" for Ukrainian nationhood. According to another view, the monuments posed no threat to Ukraine as a state, since they were only a part of history and thus should have been preserved. The deviant government actions within the memory policies, expressed through establishing a new national narrative along with preservation of the Soviet elements, led to the simultaneous formation of nationalistic and pro-Soviet narratives of interpretation of the past. Neither of these narratives had a dominant position in central Ukraine; they rather had limited numbers of active supporters. As a result, "the war of monuments" started. According to the estimations of Volodymyr Ishchenko, in one year (October 2009 - November 2010) 48 acts of vandalism towards Soviet monuments were carried out in Ukraine. ${ }^{44}$ The monuments were inscribed with obscene language, Nazi and anti-Semitic slogans, partially cracked off, painted with swastikas or even soiled with excrements. Frequently, the monuments were poured over with pink, red, or blue and yellow paint. The actions of that kind were mostly committed at night and, therefore, the offenders remained anonymous.

Wide coverage of such events in the media rekindled debates in society. Everyone faced the need to clarify their position about the Soviet statesmen monuments. A National Survey conducted in March $2013^{45}$ showed that $59.9 \%$ of all respondents expressed a negative attitude towards establishment/preservation of a Lenin statue in their city or town; $24.8 \%$ supported its preservation and $15.4 \%$ of respondents could not answer the question. Therefore, the number of supporters was quite significant, although the majority of responders were against the preservation of Lenin monuments. Analysis of the data from Vinnytsia, Kyiv and Cherkasy regions shows that the results are slightly different (see Table 1).

43 "Na Vinnychyni cholovik pryviz dodomu pamiatnyk Lenina," ["Vinnytsia Resident Brings Home Statue of Lenin,"] 20 minutes, January 24, 2012, accessed March 1, 2013, http://2ominut.ua/.

Volodymyr Ishchenko, "Fighting Fences vs. Fighting Monuments: Politics of Memory and Protest Mobilization in Ukraine," Journal of Contemporary Central and Eastern Europe 19.1-2 (2011): 12.

The research employs data of the sociological survey conducted in Ukraine as a part of the project "Region, Nation and Beyond. A Transcultural and Interdisciplinary Reconceptualization of Ukraine" held by the University of St. Gallen (Switzerland). 


\begin{tabular}{lccc} 
Region & "Positive" & "Negative" & "Do not know" \\
\hline Vinnytsia & $40.3 \%$ & $34.7 \%$ & $25 \%$ \\
\hline Cherkasy & $28.2 \%$ & $59.2 \%$ & $12.6 \%$ \\
\hline Kyiv & $14 \%$ & $73.1 \%$ & $12.8 \%$ \\
\hline City of Kyiv & $23.1 \%$ & $61.6 \%$ & $15.3 \%$ \\
\hline
\end{tabular}

TABLE 1. Attitudes towards Lenin monuments in central Ukraine

The majority in Cherkasy and Kyiv regions did not support the idea to preserve the Lenin monument in their communities. The only exception was Vinnytsia region where $40,3 \%$ of the responders supported the idea to keep or erect a Lenin monument in their town. However, in comparison to Kyiv and Cherkasy regions, Vinnytsia showed the highest level of uncertain responders $-25 \%$.

There are different reasons behind the people's desire to preserve the monuments. When answering questions about the monuments, responders expressed their attitude to a certain way of honouring a historical person. Therefore, Lenin may be considered positively by citizens of Ukraine, but it does not mean that he deserves the monuments. In some cases, preservation of the monument is motivated by its artistic value or by the fact that it is an integral part of the urban landscape. Besides, a certain number of people believe that everything has to be preserved - no matter if it is bad or good - as it is history. In turn, the main argument for those who demanded complete destruction of communist symbols was that Lenin organized political repressions in Ukraine and his statue visually represented the Soviet regime.

On the materials of fieldwork conducted in the regional centres of Vinnytsia, Kyiv and Cherkasy regions in October 2013, we can distinguish the following argument of the residents against the demounting of monuments to Lenin:

1) the monument is a part of history;

2) the dismantling of the monument would not improve people's lives;

3) financial resources and labour have been invested into the construction of the monument, therefore it should be preserved.

So, those responders, who opposed the dismantling of the monument, denied the ideological meaning of the monument, referring to its historicity and more often mentioned practical, economical issues as the reasons for preservation of the monument. On the contrary, the responders supporting the demounting of Lenin statues referred to the ideological meaning of the monument. They pointed to the fact that the monument to Lenin represented the Soviet regime and the colonial past of Ukraine within the USSR, while Lenin was presented as a villain, responsible for mass repression. Also, they mentioned that the majority of the monuments to Lenin have no artistic value, since they are replicated copies often made of cheap materials. There was a third category of respondents who did not care about the monument at all; for them, it was the responsibility of state agencies to deal with the monuments. 
When analysing people's attitudes, one should note that despite the massive presence of Lenin statues, his figure is becoming less relevant to the historical memory of Ukraine, primarily in its central part. The number of people regarding Lenin as one of the most important historical figures in the history of Ukraine is relatively insignificant. The person of Vladimir Lenin was chosen most frequently among the respondents from Vinnytsia region, by $9.3 \%$ of all respondents. In Cherkasy and Kyiv regions Lenin was mentioned only by $5.8 \%$ and $5.4 \%$ of respondents respectively, and by $5.6 \%$ in the city of Kyiv.

At the same time, it does not mean that the part of the population thinking that there is no place for Lenin statues in contemporary Ukraine is ready for radical actions to demolish them or supports such actions. For instance, on 8 December 2013, during the protests in Kyiv, several unidentified men threw a rope onto the monument to Lenin, placed on the Shevchenko Boulevard in Kyiv, and knocked it down. The protesters pulled down an 11 feet high statue with a steel wire, smashed the monument with sledgehammers and then carried off prized pieces of the sculpture. ${ }^{46}$

According to a survey conducted by the Research \& Branding Group on December 19.69\% of the responders from Kyiv denounced demolition of the Lenin statue and described it as an act of vandalism. Positive evaluation of the event was expressed by $13 \%$ of respondents, while the rest reported indifference. ${ }^{47}$ It is noteworthy that negative attitude was shared among the majority of all age groups and supporters of all main political forces. Data from this survey differs significantly from the survey conducted a few months earlier in the capital (Table 1). $61.6 \%$ of Kyiv residents expressed disagreement with preservation of the Lenin monument in the city; on the contrary, $23 \%$ of the responders supported the idea. Thus, we can assume that the majority of Kyiv residents agreed that the Lenin statue had no place in the centre of the Ukrainian capital, but, at the same time, they did not support the illegal and brutal destruction of public monuments.

Nevertheless the protest movement called Euromaidan, which had started on 21 November 2013 in Kyiv, activated the issue of the Soviet heritage in Ukraine. The demolishing of the Lenin statue on Bessarabska square on 8 December 2013 marked the beginning of a national movement for Lenin statue destruction. Iuri Syrotiuk, a member of the political party “Svoboda," called this event the end of the Soviet occupation and the beginning of the final decolonization of Ukraine ${ }^{48}$. Subverting icons to demonstrate the state's lack of control over its symbols has often been very effective. Notably, the monuments to Lenin have been "invisible" in the central

46 Uri Frieman, “The Remarkable History Behind Ukraine's Toppled Lenin Statue," The Atlantic, December 8, 2013, accessed December 9, 2013, http://www.theatlantic.com/international/ archive/2013/12/the-remarkable-history-behind-ukraines-toppled-lenin-statue/282141/.

47 The survey conducted by the company Research \& Branding Group regarding the attitudes of residents of Kyiv to the demolition of the monument to Lenin on 8th of December. "Tilky 13\% kyian khvalyly znesennia pamiatnyka Leniny" ["Only 13\% of the Kyiv residents supported the demounting of the monument to Lenin"]. Dzerkalo tyzhnia, 19 December, 2013, http://dt.ua/UKRAINE/tilki-13kiyan-shvalili-znesennya-pam-yatnika-leninu-134279_.html.

"V Kyievi zvalyly Lenina," ["Monument to Lenin Toppled in Kyiv,"] News.ru, December 8, 2013, accessed December 9, 2013, http://www.newsru.ua/ukraine/o8dec2o13/lenin.html. 
regions of Ukraine for a long time, but after Euromaidan, they became "needless monuments" and, therefore, were destroyed. Dozens of statues of the Soviet-era leader were toppled during December 2013 - February 2014 by antigovernment protestors. According to approximate reports, 218 statues of Lenin were toppled or seriously damaged in Ukraine as of 25 February 2014. Among them, 27 were in Vinnytsia region, 17 in Kyiv region and 22 in Cherkasy region. 3 Lenin monuments were dismantled in Kyiv.

Lenin statues were toppled across the territory of Ukraine by the radical activists in support of Euromaidan. This movement intensified after 2oth of February 2014, when almost one hundred people were killed in Kyiv. The "Leninfall," as Ukrainian activists called it, was perceived as part of the struggle against the criminal political regime. In general, it was not an organized and carefully planned action; at the same time, it had significant emotional impact on the citizens of Ukraine. The process of demounting was accompanied by the raising of the national flag, national anthem performance, and there were even cases when the head of the Lenin statue was symbolically brought to the monument to Taras Shevchenko. Due to the deep political crisis in Ukraine, the authorities decided not to involve themselves and not to protect the monuments. Thus, the demolishing of the monuments took on the meaning of breaking with the Soviet past and, partly, with Russia. Furthermore, it was the demonstration of protest again political power and willingness for changes in the country. Many of the activists were convinced that the Lenin statues should be replaced by monuments to the Heroes of the Maidan, activists who died for Ukraine. ${ }^{49}$ To sum up, the vision of the monument as part of a past that prevents movement to a better future became widespread after Euromaidan. Therefore, the protest itself and the tragic events in Kyiv (18-20February 2014) made the statues of Lenin even more visible and unacceptable in Ukraine. Although there were people who did not support the destruction of the monuments, their voices were silenced during the political upheaval. And as Justinian A. Jampol, the founder and executive director of The Wende Museum and Archive of the Cold War in Culver City, indicates, the removal of monuments did not necessarily resolve the complex historical problems that they represented. "Often the absence of physical reminders within the urban landscape only pushes the invisible psychological scarring further into the recesses - until it erupts."50

\section{Conclusions}

Ukraine faced multiple challenges after gaining independence; the nation's identity was not articulated and completely established, including the national narrative and the pantheon of national heroes. The diversity of collective memory reflects the various historical backgrounds of the regions, including the different experience of the Soviet era. Ukraine has not experienced lustration, and thus, many of the members of the former Communist party regained power,

49 See comments on the Internet Edition of "Ukrainska Pravda" at: http://www.pravda.com.ua/ news/2014/02/21/7015377/view_comments/.

Justinian A. Jampol, “Smashing Lenin Won't Save Ukraine,” The New York Times, March 3, 2014, accessed March 5, 2014, http://www.nytimes.com/2014/03/o4/opinion/smashing-lenin-wont-saveukraine.html?_r=o. 
not to mention that the Communist party preserved its dominant position in the Ukrainian Parliament during the nineties. These factors complicated the process of the formation of united and cohesive memory policies. Instead of rethinking and reevaluating the Soviet period in Ukrainian history, the government chose the strategy of imposing a national narrative alongside with the preservation of Soviet symbols. As a result, the Soviet period remained the most debated topic in society, while the Soviet cultural heritage was silenced and removed from public discussion.

Being unable to issue a decree for the complete dismantling of Soviet statesmen monuments and not willing to protect them, President Yushchenko passed the right to decide the fate of the monuments to local authorities. The official attitude towards the monuments was determined by the prevailing practices of collective memory and political preference in every specific region. This policy led to even stronger differentiation among regions, cities and villages.

As no consensus was reached over the fate of Soviet heritage in monumental art, and the central authorities avoided participation in the decision-making process, private initiatives aimed at the destruction or preservation of the Soviet heritage emerged. The unidentified activists damaged communist monuments in order to express their anti-Soviet views and draw public attention to the ex-Soviet relics remaining in modern Ukraine. On the contrary, part of the local population collected the artifacts of Soviet times in an attempt to protect their right to "remember." Still, without governmental control, the representation of the Soviet period in the so-called "Part of the Soviet Period" is mostly one-sided.

The revolutionary events called Euromaidan deeply influenced memory policies on the Soviet past. The fight with the criminal government and for freedom has spread rapidly to the remaining monuments to Soviet statesmen in Ukraine. The dismantling of the Lenin statue in Kyiv had symbolic meaning and led to activation of communist monument removal processes in other regions of Ukraine, especially in its central part. It must be stressed that the revolutionary situation allowed for the dismantling to happen instantly and without legal consequences.

History is filled with examples of manipulated images and defaced symbols of power. But the destruction or removal of symbols as a means of national reconciliation or as cultivation of a new collective memory is rarely successful. So, the battles over the past in Ukraine continue to unfold. At the same time, it can be stated that, as a result of events called Euromaidan, a certain vision of the political/ideological future was established in Ukraine and, according to that vision, there is no place for monuments to Lenin and other Soviet statesmen in Ukraine anymore. As the memory policies are determined not only by historical experience of the country, but also by the vision of its future.

\section{Bibliography}

Bakhanov, Konstiantyn. "Novi chasy — novi heroi: Formuvannia kultury pamiati v Ukraini." ["New Times - New Heroes: The Formation of Cultural Memory in Ukraine."] In Kultura 
istorychnoi pamiati: ievropeiskyi ta ukrainskyi dosvid, edited by Iu. Shapoval, 182-216. Kyiv: IPIEND, 2013.

Chobit, Dmytrii. "Nazdohaniaiuchy viky." ["Catching the Ages."]. Holos Ukrainy, October 2, 1992. Communist Party of Ukraine. "Meria Cherkas maie povernuty pamiatnyk Leninu na mistse!" [“Cherkasy City Hall Should Return Statue of Lenin to Its Place!"] August 7, 2012. Accessed September 10, 2013. http://www.kpu.ua/ru/41515/meriya-cherkas-maye-povernutipam\%25e2\%2580\%2599yatnik-leninu-na-misce.

"Decision of the Kyiv Administrative Court of Appeals 2a-817/11/2316, August 2, 2012." Accessed December 13, 2013. http://pravoscope.com/act-uxvala-sudu-2a-817-11-2316-tverdoxlib-va-o2-08-2012-administrativni-spravi-s.

Decree of the Parliament of Ukraine No 1468-XII/1991 "On Banning the Communist Party of Ukraine.” Accessed December 13, 2014. http://search.ligazakon.ua/__doc2.nsf/link1/ T1468oo.html.

Decree of the President of Ukraine No 1143/2001 "Issues on the Usage of the State Symbols of Ukraine." Accessed December 14, 2014. http://zakon4.rada.gov.ua/laws/show/79/2001.

Decree of the President of Ukraine No 250/2007 "Commemoration of the 75th Anniversary of the Holodomor of 1932-1933 in Ukraine." Accessed December 13, 2013. http://un.mfa. gov.ua/ua/act/open/id/2034.

Decree of the President of Ukraine No 432/20o9 "On Additional Measures to Commemorate the Victims of the Holodomor of 1932-1933 in Ukraine." Accessed December 13, 2013. http://zakon4.rada.gov.ua/laws/show/432/2009.

"Demontirovan pamiatnik Leninu v Lvove." ["Monument to Lenin Demounted in Lviv."] Pravda Ukrainy, September 16, 199 o.

"Demontirovan pamiatnyk Leninu." ["Monument to Lenin Demounted."] Pravda Ukrainy, August, 2, 1990.

Frieman, Uri. “The Remarkable History Behind Ukraine's Toppled Lenin Statue." The Atlantic, December 8, 2013. Accessed December 9, 2013. http://www.theatlantic.com/international/ archive/2013/12/the-remarkable-history-behind-ukraines-toppled-lenin-statue/282141/.

Harvey, David. "Heritage Pasts and Heritage Presents: Temporality, Meaning and the Scope of Heritage Studies." International Journal of Heritage Studies 7.4 (2001): 319-38.

Hrytsak, Iaroslav. "Istoriia v osobakh: Do formuvannia istorychnoi pamiati v Ukraini, 1991-2011." ["Personalities: On the Issue of the Formation of Historical Memory in Ukraine, 1991-2011."] In Kultura istorychnoi pamiati: ievropeiskyi ta ukrainskyi dosvid, edited by Iu. Shapoval, 231-250. Kyiv: IPIEND, 2013.

Ishchenko, Volodymyr. "Fighting Fences vs. Fighting Monuments: Politics of Memory and Protest Mobilization in Ukraine." Journal of Contemporary Central and Eastern Europe 19.1-2 (2011): 1-12.

Jampol, J. A. “Smashing Lenin Won't Save Ukraine." The New York Times, March 3, 2014. Accessed March 5, 2014. http://www.nytimes.com/2014/o3/o4/opinion/smashing-lenin-wont-saveukraine.html?_r=o.

"Kalynivka: My ne khochemo Lenina." [“Kalynivka: We do not Want Lenin."] 20 Minutes, January 22, 2013. Accessed January 25, 2013. http://2ominut.ua/Novyny-Kalynivky/VidChytachiv/1025965o. 
Kasianov, Georgii. "Holodomor i stroitelstvo natsii." ["The Holodomor and Nation Building."] Pro et Contra, 3-4 (2009): 24-42.

Kasianov, Georgii. Ukraina 1991-2007: Narysy novitnoi istorii [Ukraine 1991-2007: Essays on Contemporary History]. Kyiv: Nash chas, 2008.

"Kommunisty Kolomyi protestuiut." ["Communists Protest in Kolomyia."] Pravda Ukrainy, August 24, 1990.

Lehr, John, and Natalia Aponiuk. "Memory, Myth, and Monuments: The Commemoration of a Contested Past in Western Ukraine." Memory Connection 1.1 (2011): 212-28.

"Leninopad tryvaie: vozhdia skynuly v Kanevi, Mykolaievi, Khersoni." ["The 'Lenin Fall' Continues: Lenin Toppled in Kaniv, Mykolaiv, Kherson."] TSN, February 22, 2014. Accessed March 1, 2014. http://tsn.ua/ukrayina/leninopad-trivaye-vozhdya-skinuli-v-kanevimikolayevi-hersoni-336o67.html.

Light, Duncan. "An Unwanted Past: Contemporary Tourism and the Heritage of Communism in Romania." International Journal of Heritage Studies 6.2 (2000): 145-6o.

Meusburger, Peter. "Cultural Memories: Introduction." In Cultural Memories. The Geographical Point of View, edited by. P. Meusburger, E. Wunder, and M. Heffernan, 3-15. Dordrecht: Springer, 2006.

Mihaitva, Oksana. "Sotsialnyi prostir mista: Mozhlyvosti 'prochytannia' ta upravlinnia." ["The Social Space of the City: Possibilities of 'Reading' and Management."] Herald of Donetsk National University. Sociology Series 8.3 (2007): 413-22.

Nahorna, Larysa. "Polityka pamiati ta ii oriientatsiina misiia." ["The Politics of Memory and its Orientation Mission."] In Kultura istorychnoi pamiati: ievropeiskyi ta ukrainskyi dosvid, edited by Iu. Shapoval, 114-41. Kyiv: IPIEND, 2013.

"Na Vinnychyni cholovik pryviz dodomu pamiatnyk Lenina." ["Vinnytsia Resident Brings Home Statue of Lenin.”] 20 Minutes, January 24, 2012. Accessed March 1, 2013. http://2ominut.ua/.

Nora, Pierre. "Vsemirnoie torzhestvo pamiati." ["The Worldwide Celebration of Memory."] Nieprikosnoviennyi zapas 2-3 (2005). Accessed October 10, 2014. http://magazines.russ.ru/ $\mathrm{nz} / 2005 / 2 /$ nora22.html.

"Pamiatnyk Leninu v Chyhyryni." ["The Monument to Lenin in Chyhyryn."] Shukach, September 20, 2012. Accessed February 1, 2013. http://www.shukach.com/uk/node/13969.

"Pamiatnik Leninu v Kanevi proponuiut znesty miski deputaty." ["Deputies Propose to Dismantle Monument to Lenin in Kaniv."] Kaniv, April 2, 2013. Accessed April 20, 2013. http://www. kaniv.net/news.php? $\mathrm{p}=24406 \& \mathrm{cvc}=0$.

"Pamiatnyk-pryvyd, abo kudy podily Lenina z tsentralnoi ploshchi Vinnytsi." ["The MonumentPhantom, or where the Lenin Monument was Taken from the Central Square of Vinnytsia"]. 20 Minutes, March 13, 2013.

Pavlenko, Borys. "Illich z Talnoho pishov unochi." ["Illich Left Talne at Night."] Personal, September 2-8, 2009.

"Pres-konferentsiia Leonida Kravchuka." ["The Press Conference of Leonid Kravchuk."] Pravda Ukrainy, September 14, 1990. 
Resolution of the Parliament of the USSR No 270-XII/1990 "On the Violation of the Law of the Ukrainian SSR 'On the Protection and Use of Historical and Cultural Monuments." The Bulletin of the Parliament of USSR 40 (1990): 536.

"V Cherkassakh vo vremia demontazha pamiatnik Lenina raskololsia na chasti." ["Monument to Lenin Split into Parts during its Dismantling in Cherkassy."] News.ru, November 28, 2008. Accessed August 10, 2013. http://rus.newsru.ua/ukraine/28nov20o8/lenin1.html.

"V Kyievi zvalyly Lenina." ["Monument to Lenin Toppled in Kyiv."] News.ru, December 8, 2013. Accessed December 9, 2013. http://www.newsru.ua/ukraine/o8dec2013/lenin.html.

"Voina s pamiatnikami." ["Monuments at War"]. Pravda Ukrainy, July 21, 1990.

"Vid vinnytskykh komunistiv z Iampolia 'vtik' Lenin." ["Lenin 'Escapes' from Communists in Iampil.”] Vinnitsa.info, September 25, 2013. Accessed November 1, 2013. http://www. vinnitsa.info/news/vid-vinnitskih-komunistiv-z-yampolya-vtik-lenin.html.

Zhytomyr.info. "Ieshche v odnom ukrainskom gorode demontirovan pamiatnik Leninu." ["Monument to Lenin Demounted in Yet Another Ukrainian City."] Accessed June 22, 2012. http://www.zhitomir.info/news_109152.html.

"Znaky totalitarnoho Molokhu, iaki ne uviishly do Derzhavnoho reiestru nerukhomyh pamiatok Ukrainy." ["Symbols of Totalitarian Remnants, not Included in the State Register of Ukraine."] Kultura i zhyttia 49-52 (2009): 19-41.

\section{(2)}

Oleksandra Gaidai is a PhD student at the Institute of History of Ukraine, National Academy of Science of Ukraine, Department of Contemporary History and Politics. She received her Master of Arts in History in 2011 (National University of Kyiv-Mohyla Academy). In 2013 she was a Junior Visiting Fellow at the Graduate Institute of International and Development Studies, Geneva, Switzerland. She participated in the Project "Region, Nation and Beyond. A Transcultural and Interdisciplinary Reconceptualization of Ukraine," held by the University of St. Gallen, Switzerland. As the part of this project she analysed historical memory and representations of the Soviet past among students of central Ukrainian universities. The results were published in the Ukrainian Historical Journal 6 (2014). Her research interests include the theories of cultural heritage and politics of memory, the features of the post-Soviet cityscape, and commemorations in Ukraine after 1991. 